\title{
ANALISIS LAPORAN KEUANGAN UNTUK MENGUKUR KINERJA KEUANGAN PERUSAHAAN TELEKOMUNIKASI PT. SMARTFREN TELECOM TBK TAHUN 2017-2018
}

\author{
Yana Aprilia Manuhutu ${ }^{1}$, Herman Karamoy $^{2}$, Sintje Rondonuwu ${ }^{3}$ \\ 1,2,3 Jurusan Akuntansi, Fakultas Ekonomi dan Bisnis, Universitas Sam Ratulangi, J1. Kampus Bahu, Manado, \\ 95115, Indonesia \\ E-mail: yanaaprilia431@gmail.com
}

\begin{abstract}
Financial statements are the final process in the accounting process that has an important role for measuring and evaluating the performance of a company. Companies in Indonesia, especially companies that go public are required to make financial reports every period. The financial statements have the purpose of providing information about the company's financial position, performance, and cash flow which is beneficial for most report users in order to make economic decisions and show management's stewardship for the use of resources entrusted to them. This study aims to determine, the results of the analysis of Liquidity Ratios, Solviabilities, Profitability, and Activities of the financial performance of companies listed on the Indonesia Stock Exchange (Study on PT. Smartfren Telcom Tbk 2017-2018). The analytical method used is descriptive qualitative analysis. The result of this study shows that the financial performance of PT. Smartfren Telecom.Tbk is not going well yet. This is seen through the results of an analysis which shows that the instability of the company's financial performance produced between 2017 and 2018. Telecommunications companies must further improve the company's performance by reducing the amount of debt and increasing operating cash flow.
\end{abstract}

Keywords: financial reports; financial performance; Indonesia Stock Exchange; current ratio; quick ratio; debt to asset ratio.

\section{PENDAHULUAN}

Laporan keuangan merupakan proses akhir akuntansi yang memiliki peranan penting bagi pengukuran dan penilaian kinerja sebuah perusahaan. Perusahaan-perusahaan di Indonesia, khususnya perusahaan go public diwajibkan membuat laporan keuangan setiap periodenya. Laporan keuangan tersebut mempunyai tujuan untuk memberikan informasi tentang posisi keuangan, kinerja, dan arus kas perusahaan yang bermanfaat bagi sebagian besar kalangan pengguna laporan dalam rangka membuat keputusan-keputusan ekonomi serta menunjukkan pertanggungjawaban manajemen atas penggunaan sumber-sumber daya yang dipercayakan kepada mereka".

Dewasa ini, banyak perusahaan berskala besar atau kecil baik yang bersifat profit maupun non profit, mempunyai perhatian yang besar di bidang keuangan. Perkembangan dunia usaha yang semakin maju, persaingan antara satu perusahaan dengan perusahaan lainnya semakin tinggi mengakibatkan adanya perusahaan yang tiba-tiba mengalami kemunduran. Agar perusahaan dapat bertahan dan bisa tumbuh berkembang, perusahaan harus mencermati kondisi dan kinerja perusahaan, guna mengetahui dengan tepat bagaimana kondisi dan kinerja perusahaan maka dibutuhkan pula suatu analisis yang tepat.

Laporan keuangan bagi suatu perusahaan hanyalah sebagai alat penguji dari pekerjaan bagian pembukuan. Perkembangan selanjutnya, informasi akuntansi menjadi alat untuk mengukur kinerja keuangan suatu perusahaan. Pengukuran kinerja keuangan bermanfaat untuk pengetahuan penggunaan sumber-sumber ekonomi, kewajiban yang harus dipenuhi dan 
modal yang dimiliki oleh perusahaan, serta hasil-hasil yang telah dicapai perusahaan. Melalui hasil analisis tersebut, dapat diketahui pengunaan sumber-sumber ekonomi, kewajiban yang harus dipenuhi dan modal yang dimiliki oleh perusahaan, serta hasil-hasil yang telah dicapai perusahaan tersebut.

Kinerja keuangan suatu perusahaan dapat diukur dan dilihat melalui laporan keuangan dengan cara menganalisis laporan keuangan. Harahap (2014:25) mengatakan bahwa kegiatan analisis laporan keuangan merupakan salah satu media untuk mendapatkan informasi yang lebih banyak, lebih baik, akurat, dan dijadikan sebagai bahan dalam proses pengambilan keputusan. Analisis laporan keuangan merupakan alat yang sangat penting untuk memperoleh informasi yang berkaitan dengan posisi keuangan perusahaan serta hasil-hasil yang telah dicapai sehubungan dengan pemilihan stategi perusahaan yang akan ditetapkan. Selain itu, dengan melakukan analisis laporan keuangan perusahaan, maka pimpinan perusahaan dapat mengetahui keadaan finansial perusahaan serta hasil-hasil yang telah dicapai diwaktu lampau dan diwaktu yang sedang berjalan.

\section{TINJAUAN PUSTAKA}

Akuntansi adalah suatu proses mencatat, mengklasifikasi, meringkas mengola dan menyajikan data transaksi serta kejadian yang berhubungan dengan keuangan, sehingga laporan keuangan perusahaan bisa dengan mudah dimengerti untuk pengambilan suatu keputusan serta tujuan lainnya. Akuntansi adalah sistem informasi dan pengukuran yang mengidentfikasi, mencatat dan mengkomunikasikan informasi yang relevan, dapat diandalkan, dan dapat dibandingkan tentang kegiatan bisnis organisasi (Wild et al. 2014:3). Menurut Suwardjono (2014:10), akuntansi dideskripsikan sebagai seperangkat alat yang mempelajari implementasi penyedia jasa berupa laporan keuangan kuantitatif bagian organisasi dalam suatu lingkup negara tertentu dengan cara penyajian informasi tersebut kepada kelompok yang berkepentingan untuk dijadikan alasan dalam pengambilan hasil ekonomi.

Menurut Soemarso (2016:34), laporan keuangan adalah laporan yang disajikan untuk kepentingan para pembuat keputusan, terutama pihak di luar perusahaan, mengenai posisi keuangan dan hasil usaha perusahaan. Menurut Harahap (2014:190), analisis laporan keuangan berarti menguraikan pos-pos laporan keuangan menjadi unit informasi yang lebih kecil dan melihat hubungannya yang bersifat signifikan atau yang mempunyai makna antara satu dengan yang lain baik antara data kuantitatif maupun data non-kuantitatif dengan tujuan untuk mengetahui kondisi keuangan lebih dalam yang sangat penting dalam proses menghasilkan keputusan yang tepat. Analisis laporan keuangan dilakukan untuk mencapai beberapa tujuan, misalnya dapat digunakan sebagai alat screening awal dalam memilih alternatif investasi atau merger; sebagai alat forecasting mengenai kondisi dan kinerja keuangan di masa datang; sebagai proses diagnosis terhadap masalah-masalah manajemen, operasi atau masalah lainnya; atau sebagai alat evaluasi terhadap manajemen (Djarwanto, 2016:41). Menurut Harahap (2014:419), kinerja adalah penentuan secara periodik efektifitas operasional suatu organisasi, bagaimana organisasi dan karyawan berdasarkan sasaran dan kriteria yang telah ditetapkan sebelumnya sehingga dapat disimpulkan bahwa kinerja keuangan adalah prestasi yang dicapai oleh perusahaan di bidang keuangan dalam suatu periode tertentu yang mencerminkan tingkat kesehatan perusahaan pada bidang tersebut.

Rasio dalam analisis laporan keuangan adalah suatu angka yang menunjukkan hubungan antara suatu unsur dengan unsur lainnya dalam laporan keuangan. Hubungan antara unsur-unsur laporan keuangan tersebut dinyatakan dalam bentuk matematis yang sederhana (Djarwanto. 2016:143). Rasio likuiditas adalah rasio yang bertujuan untuk mengetahui kemampuan perusahaan dalam membayar kewajiban jangka pendek meliputi current ratio dan quick ratio. Pedoman (rule of thumb) dalam menganalisis adalah current 
ratio antara $100 \%$ sampai dengan 200\%. Dimana nilai $200 \%$ berarti banyak aktiva menganggur (Harahap, 2014:297). Rasio solvabilitas adalah rasio untuk mengetahui kemampuan perusahaan dalam membayar kewajiban jika perusahaan tersebut dilikuidasi. Rasio ini meliputi debt to assets ratio yaitu rasio ini menekankan pentingnya pendanaan hutang dengan jalan menunjukkan persentase aktiva perusahaan yang didukung oleh hutang. Rule of thumb dari rasio solvabilitas adalah maksimal 100\%, artinya perusahaan banyak mengandalkan modal internal, bukan utang (Darsono dan Ashari, 2005:54). Rasio profitabilitas adalah rasio yang bertujuan untuk mengetahui kemampuan perusahaan dalam menghasilkan laba. Rasio ini meliputi Return on Assets dan Return on Equity. Rule of thumb pada setiap rasio ini adalah bahwa hasil perhitungan rasio harus lebih besar dari bunga deposito berjangka satu tahun. Jika hasil perhitungan rasio lebih kecil dari suku bunga satu tahun, maka hasil investasi yang dilakukan lebih kecil daripada investasi pada deposito berjangka (Darsono dan Ashari, 2005:56). Rasio aktivitas adalah rasio yang menggambarkan aktivitas yang dilakukan perusahaan dalam menjalankan operasinya. Rasio ini meliputi Inventory Turnover dan Total Assets Turnover (TATO). Kemampuan perusahaan dalam menggunakan aktiva yang dimiliki untuk menghasilkan penjualan digambarkan dalam rasio ini. Hasil analisis rasio dapat memberikan informasi efektivitas penggunaan aktiva atas penjualan.

Penelitian terdahulu. Hasil penelitian Trianto (2017) yang menggunakan Current Ratio dan Quick Ratio guna mengukur kinerja keuangan menunjukkan bahwa pada tahun 2014 kondisi keuangan perusahaan cukup baik karena rasio kinerja keuangan berada di atas rata-rata industry sedangkan pada 2015 dan 2016 menunjukkan kondisi keuangan perusahaan tidak baik karena rasio di bawah rata-rata industri. Rasio cepat pada tahun 2015 dan 2016 menunjukkan kondisi keuangan perusahaan tidak baik, karena rasio di bawah rata-rata industri. Hasil penelitian Ramadhan dan Syarfan (2016) menunjukkan bahwa PT. Ricky Kurniawan Kertapersada mempunyai kinerja yang termasuk kategori baik berdasarkan current ratio dan quick ratio, memiliki aktivitas yang baik dalam perputaran asset, dan secara umum baik dari sudut profitabilitas, walaupun kurang baik dari segi solvabilitas. Hasil penelitian Susianti (2018) menemukan bahwa PT. Gudang Garam Tbk dinyatakan likuid, solvable, dan memiliki profitabilitas yang baik secara keseluruhan. Hasil penelitian Arifin dan Primandari (2015) menunjukkan bahwa PT. Kereta Api Indonesia bersama anak perusahaannya memiliki kinerja keuangan yang sangat baik. Dengan rasio profitabilitas yang dimiliki saat ini dapat membantu PT. Kereta Api Indonesia untuk meningkatkan pelayanan dalam bidang transportasi kereta api di Indonesia. Hasil penelitian Fitri (2017) yang menggunakan rasio profitabilitas untuk menganalisis laporan keuangan PT. Adhi Karya (Persero) Tbk menyatakan bahwa analisis laporan keuangan PT. Adhi Karya (Persero) Tbk menunjukkan bahwa kondisi PT. Adhi Karya (Persero) Tbk adalah baik. Meskipun laba masih relatif kecil tetapi cukup stabil dan perusahaan tidak mengalami kerugian dalam operasinya. Hasil penelitian Sulastri dan Hapsari (2015) yang menggunakan rasio likuiditas, solvabilitas dan profitabilitas untuk mengukur kinerja keuangan perusahaan menyatakan bahwa analisa rasio terhadap PT. Andalan Finance Indonesia Semarang. Rasio likuiditas dilihat dari Current Ratio tahun 2011 lebih baik dibanding tahun 2012 dan tahun 2013. Quick Ratio tahun 2011 juga lebih baik dibanding tahun 2012 dan tahun 2013. Rasio solvabilitas apabila dilihat dari Debt to Total Asset Ratio tahun 2012 dan tahun 2013 lebih baik dibanding tahun 2011. Debt to Equity Ratio tahun 2012 dan tahun 2013 juga lebih baik dibanding tahun 2011. Rasio profitabilitas dilihat dari profit margin tahun 2012 dan tahun 2013 mengalami penurunan dibanding tahun 2011. Return On Equity tahun 2012 dan tahun 2013 juga mengalami penurunan dibanding tahun 2011. Hasil penelitian Barus et al. (2017) yang menggunakan rasio likuiditas, aktivitas, leverage dan profitabilitas untuk mengukur kinerja keuangan perusahaan menunjukkan bahwa analisis rasio keuangan yaitu rasio likuiditas, rasio 
aktivitas, rasio leverage dan rasio profitabilitas di Indonesia periode 2013-2015 menunjukkan bahwa kinerja keuangan oleh PT. Astra Otoparts, Tbk lebih baik dari pada PT. Good year Indonesia, Tbk. Hasil penelitian Tanor et al. (2015) yang menggunakan rasio likuiditas, solvabilitas dan profitabilitas untuk mengukur kinerja keuangan perusahaan menunjukkan bahwa likuiditas Bank Artha Graha mampu memenuhi kewajiban jangka pendek yang dimiliki. Hasil solvabilitas memperlihatkan kemampuan bank dalam permodalan yang dimiliki mampu untuk menutupi penurunan maupun kerugian. Hasil profitabilitas memperlihatkan bank memiliki hasil rasio yang terus meningkat. Ketiga rasio keuangan sesuai dengan standar yang ditentukan BI. Kondisi keuangan Bank Artha Graha masih dalam keadaan baik dan dapat memenuhi kewajiban terhadap pihak ketiga.

\section{METODE PENELITIAN}

Jenis penelitian yang digunakan adalah kualitatif deskriptif untuk mengetahui kinerja perusahaan telekomunikasi PT. Smartfren. Penelitian ini dilakukan di Bursa Efek Indonesia di Fakultas Ekonomi dan Bisnis sebagai penyedia data penelitian. Metode pengumpulan data yang digunakan untuk penelitian ini adalah dokumentasi. Dokumentasi yaitu teknik pengumpulan data dengan melakukan dokumentasi. Dokumentasi pada penelitian ini adalah laporan Keuangan Perusahaan PT. Smartfren Telcom Tbk yang terdaftar di Bursa Efek Indonesia Periode 2017-2018. Dokumentasi merupakan metode pengumpulan data pelengkap untuk memperoleh data.

Metode analisis yang digunakan dalam penelitian ini adalah metode analisis deskriptif, yaitu suatu metode yang dilakukan dengan cara mengumpulkan, menyajikan, serta menganalisis data sehingga diperoleh gambaran yang cukup jelas tentang masalah yang dihadapi, kemudian ditarik suatu kesimpulan sesuai keadaan yang sebenarnya. Penelitian desktiptif adalah sebuah penelitian yang bertujuan untuk memberikan atau menjabarkan suatu keadaan atau fenomena yang terjadi saat ini dengan menggunakan prosedur ilmiah untuk menjawab masalah secara aktual (Sugiyono: 2011).

\section{HASIL PENELITIAN DAN PEMBAHASAN}

\subsection{Hasil penelitian}

PT. Smartfren Telecom Tbk didirikan pada bulan Desember tahun 2002 dengan nama PT. Mobile-8 Telecom. Pada bulan Januari 2011, perseroan melakukan aksi korporasi dengan mengakuisisi PT. Smart Telecom (Smartel). Perseroan melakukan perubahan nama menjadi PT. Smartfren Telecom Tbk di bulan Maret 2011 dimana sinergi dilakukan di berbagai aspek untuk mengembangkan infrastruktur jaringan, meningkatkan infrastruktur jaringan, meningkatkan efisiensi operasional, memperluas jaringan distribusi dan pemasaran, serta pemakaian satu brand yaitu "Smartfren". Pada tanggal 15 Nopember 2006, FREN memperoleh pernyataan efektif dari Bapepam-LK untuk melakukan Penawaran Umum Perdana Saham FREN (IPO) kepada masyarakat sebanyak 3.900.000.000 dengan nilai nominal Rp100,- per saham dengan harga penawaran Rp225,- per saham. Saham-saham tersebut dicatatkan pada Bursa Efek Indonesia (BEI) pada tanggal 29 November 2006.

\subsection{Pembahasan}

Rasio likuiditas adalah rasio yang bertujuan untuk mengetahui kemampuan perusahaan dalam membayar kewajiban jangka pendek, meliputi current ratio dan quick ratio. Tabel 1 menunjukan bahwa pada tahun 2017 perusahaan memiliki perputaran aset lancar sebanyak 0,400 kali dari total kewajiban lancar, sehingga Rp. 1 kewajiban lancar dijaminkan oleh Rp. 0,400 aset lancar. Pada tahun 2018 perusahaan memiliki perputaran asset lancar sebanyak 0,254 kali dari total kewajiban lancar atau dengan kata lain bahwa setiap Rp. 1 kewajiban lancar dijamin oleh Rp. 0,254 aset lancar. 
Tabel 1. Current Ratio

\begin{tabular}{cccc}
\hline Tahun & Aset Lancar & Kewajiban Lancar & Perputaran \\
\hline 2017 & 2.570 .255 & 6.411 .202 & 0,400 \\
2018 & 1.996 .682 & 7.839 .761 & 0,254 \\
\hline
\end{tabular}

Sumber : Data yang diolah, 2019

Tabel 2 menunjukan bahwa pada tahun 2017 perusahaan memiliki aset lancar sebanyak 0,341 kali dari total kewajiban lancar atau dengan kata lain bahwa setiap Rp. 1 kewajiban lancar dijamin oleh Rp. 0,341 aset lancar, sedangkan pada tahun 2018 perusahaan memiliki asset lancar sebanyak 0,232 kali dari total kewajiban lancar atau dengan kata lain bahwa setiap Rp. 1 kewajiban lancar dijamin oleh Rp. 0,232 aset lancar.

Tabel 2. Quick Ratio

\begin{tabular}{ccccc}
\hline Tahun & Aset lancar & Persediaan & Kewajiban Lancar & Perputaran \\
\hline 2017 & 2.570 .255 & 382.345 & 6.411 .202 & 0,341 \\
2018 & 1.996 .682 & 172.734 & 7.839 .761 & 0,232 \\
\hline
\end{tabular}

Sumber : Data yang diolah, 2019

Rasio solvabilitas adalah rasio untuk mengetahui kemampuan perusahaan dalam membayar kewajiban jika perusahaan tersebut dilikuidasi. Rasio ini meliputi debt to assets ratio. Tabel 3 menunjukan bahwa pada tahun 2017 aset perusahaan sebanyak 0,616 atau $61,6 \%$ di oleh biayai oleh hutang dan sisanya $38,4 \%$ di biayai oleh aset perusahaan, sedangkan pada tahun 2018 aset perusahaan sebanyak 0,735 atau 73,5\% di oleh biayai oleh hutang dan sisanya $26,5 \%$ di biayai oleh aset perusahaan.

Tabel 3. Debt to Assets Ratio

\begin{tabular}{cccc}
\hline Tahun & Total Hutang & Total Aset & Perputaran \\
\hline 2017 & 14.869 .630 & 24.114 .500 & 0,616 \\
2018 & 18.775 .426 & 25.535 .298 & 0,735 \\
\hline
\end{tabular}

Sumber : Data olahan, 2019

Rasio profitabilitas adalah rasio yang bertujuan untuk mengetahui kemampuan perusahaan dalam menghasilkan laba. Rasio ini meliputi return on assets dan return on equity. Tabel 4 menunjukan bahwa pada tahun 2017 setiap Rp. 1 total asset turut berkontribusi menciptakan Rp. 0,046 laba bersih, sedangkan bahwa pada tahun 2018 setiap Rp. 1 total asset turut berkontribusi menciptakan Rp. 0,028 laba bersih.

Tabel 4. Return on Assets

\begin{tabular}{cccc}
\hline Tahun & Laba bersih & Total Aset & Perputaran \\
\hline 2017 & 1.121 .316 & 24.114 .500 & 0,046 \\
2018 & 738.036 & 25.535 .298 & 0,028 \\
\hline
\end{tabular}

Sumber : Data olahan, 2019

Tabel 5 menunjukan bahwa pada tahun 2017 setiap Rp. 1 total ekuitas turut berkontribusi menciptakan Rp. 0,121 laba bersih, sedangkan bahwa pada tahun 2018 setiap Rp. 1 total ekuitas turut berkontribusi menciptakan Rp. 0,109 laba bersih. 
Tabel 5. Return on Equity

\begin{tabular}{cccc}
\hline Tahun & Laba Bersih & Total Ekuitas & Perputaran \\
\hline 2017 & 1.121 .316 & 9.244 .870 & 0,121 \\
2018 & 738.036 & 6.759 .872 & 0,109 \\
\hline
\end{tabular}

Sumber : Data olahan, 2019

Rasio aktivitas adalah rasio yang menggambarkan aktivitas yang dilakukan perusahaan dalam menjalankan operasinya. Rasio ini meliputi Inventory Turn Over dan Total Assets Turn Over (TATO). Tabel 6 menunjukan bahwa pada tahun 2017 kemampuan dana yang tertanam dalam persediaan berputar dalam suatu periode tertentu. Setiap Rp. 1 persediaan mampu menghasilkan penjualan bersih sebesar Rp. 0,012. Sedangkan pada tahun 2018 kemampuan dana yang tertanam dalam persediaan berputar dalam suatu periode tertentu. Setiap Rp. 1 persediaan mampu menghasilkan penjualan bersih sebesar Rp. 0,022.

Tabel 6. Inventory Turn Over

\begin{tabular}{cccc}
\hline Tahun & Penjualan & Persediaan & Perputaran \\
\hline 2017 & 4.668 .496 & 382.345 & 0,012 \\
2018 & 3.949 .749 & 172.734 & 0,022 \\
\hline
\end{tabular}

Sumber : Data olahan, 2019

Tabel 7 menunjukan bahwa pada tahun 2017 kemampuan dana yang tertanam dalam persediaan berputar dalam suatu periode tertentu. Setiap Rp. 1 aset mampu menghasilkan penjualan bersih sebesar Rp. 0,193. Sedangkan pada tahun 2018 kemampuan dana yang tertanam dalam persediaan berputar dalam suatu periode tertentu. Setiap Rp. 1 aset mampu menghasilkan penjualan bersih sebesar Rp. 0,154.

Tabel 7. Total Assets Turn Over (TATO)

\begin{tabular}{cccc}
\hline Tahun & Penjualan & Total Aset & Perputaran \\
\hline 2017 & 4.668 .496 & 24.114 .500 & 0,193 \\
2018 & 3.949 .749 & 25.535 .298 & 0,154 \\
\hline
\end{tabular}

Sumber : Data olahan, 2019

\section{KESIMPULAN DAN SARAN}

\subsection{Kesimpulan}

Berdasarkan hasil analisis rasio likuiditas, solvabilitas, profitabilitas, dan aktivitas dimana rasio likuiditas adalah rasio yang bertujuan untuk mengetahui kemampuan perusahaan dalam membayar kewajiban jangka pendek. Rasio solvabilitas adalah rasio untuk mengetahui kemampuan perusahaan dalam membayar kewajiban jika perusahaan tersebut dilikuidasi. Rasio profitabilitas adalah rasio yang bertujuan untuk mengetahui kemampuan perusahaan dalam menghasilkan laba. Kemudian yang terakhir rasio aktivitas adalah rasio yang menggambarkan aktivitas yang dilakukan perusahaan dalam menjalankan operasinya. Maka dapat disimpulkan bahwa kinerja keuangan perusahaan PT. Smartfren Telecom. Tbk belumlah berjalan dengan baik. Hal ini dilihat melalui hasil analisis yang mempelihatkan bahwa ketidakstabilan kinerja keuangan perusahaan yang dihasilkan antara tahun 2017 dan tahun 2018.

\subsection{Saran}

Berdasarkan hasil tersebut maka Perusahaan Telekomunikasi sebaiknya meningkatkan kinerja perusahaan dengan mengurangi jumlah hutang dan meningkatkan arus kas operasi. Jika perusahaan lebih meningkatkan hal tersebut dan berusaha memperbaiki masalah-masalah tersebut, maka pasti ditahun selanjutnya kinerja perusahaan akan meningkat. 


\section{DAFTAR PUSTAKA}

Arifin, S., \& Primandari, L. A. (2015). Analisis laporan keuangan untuk mengukur kinerja keuangan berdasarkan rasio profitabilitas pada PT. Kereta Api Indonesia (PERSERO) dan Anak Perusahaan. Akutansi Bisnis \& Manajemen (ABM), 22(2), 115-123. http://178.128.26.140/index.php/jabm/article/view/92

Barus, M. A., Sudjana, M., \& Sulasmiyati, S. (2017). Penggunaan rasio keuangan untuk mengukur kinerja keuangan perusahaan (studi pada PT. Astra Otoparts, Tbk dan PT. Goodyer Indonesia, Tbk yang go public di bursa efek indonesia). Jurnal Administrasi Bisnis. $\quad 44(1)$, 154-163.

http://administrasibisnis.studentjournal.ub.ac.id/index.php/jab/article/view/1740

Darsono \& Ashari. (2005). Laporan keuangan, Edisi I. Yogyakarta: Liberty.

Djarwanto, P. S. (2016). Pokok-pokok analisis laporan keuangan, Edisi 2. Yogyakarta: BPFE. Fitri, G. (2017). Analisa laporan keuangan untuk mengukur kinerja perusahaan ( Studi kasus PT. Adhi Karya (Persero) Tbk. Jurnal Akuntansi Barelang. 2(1), 24-35. http://ejournal.upbatam.ac.id/index.php/jab/article/view/1599

Harahap, S. S. (2014). Analisis kritis atas laporan keuangan, Edisi 1. Jakarta: PT. Raja Grafindo Persada.

Ramadhan, K. D., \& Syarfan, L. O., (2016). Analisis laporan keuangan dalam mengukur kinerja perusahan pada PT. Ricky Kurniawan Kertapersada (Makin Group) Jambi. Jurnal Valuta: Jurnal Administrasi Bisnis, Manajemen dan Ekonomi. 2(2), 190-207. https://journal.uir.ac.id/index.php/valuta/article/view/1150

Suwardjono. (2014). Teori akuntansi: Perekayasaan pelaporan keuangan, Edisi 3. Yogyakarta: Badan Penerbitan Fakultas Ekonomi.

Soemarso. (2016). Akuntansi Suatu Pengantar. Edisi Keempat. Jakarta: PT. Rineka Cipta.

Sugiyono. (2011). Metode penelitian kuantitatif kualitataif dan kombinasi (mixed methods). Bandung: Alfabeta.

Sulastri, P., \& Hapsari, N. M. (2015). Analisa rasio keuangan untuk menilai kinerja keuangan perusahaan (Studi kasus pada PT. Andalan Finance Indonesia tahun 2011-2013). Jurnal Ekonomi Manajemen Akuntansi. 22(38), 1-17. https://ejurnal.stiedharmaputrasmg.ac.id/index.php/JEMA/article/view/214

Susianti, I. (2018). Analisis laporan keuangan untuk menilai kinerja keuangan pada PT. Gudang Garam Tbk. pada periode 2013-2015. Jurnal Simki-Economic. 2(2), 3-11. http://simki.unpkediri.ac.id/detail/13.1.02.02.0519

Tanor, M. O., Sabijono, H., Walandouw, S. K. (2015). Analisis laporan keuangan dalam mengukur kinerja keuangan pada PT. Bank Artha Graha Internasional, Tbk. Jurnal EMBA: Jurnal Riset Ekonomi, Manajemen, Bisnis dan Akuntansi, 3(3), 639-649. https://ejournal.unsrat.ac.id/index.php/emba/article/view/9535

Trianto, A. (2017). Analisis laporan keuangan sebagai alat untuk menilai kinerja keuangan perusahaan pada PT. Bukit Asam (Persero) Tbk Tanjung Enim. Jurnal Ilmiah Ekonomi Masa Kini. $\quad$ 8(3), 1-10. http://ejournal.uigm.ac.id/index.php/EGMK/article/view/346.

Wild, J. J., Shaw, K. W., \& Chiappetta, B. (2014). Financial accounting information for decisions is an asian adaption of fundamental accounting, $20^{\text {th }}$ Edition. Singapore: Mc Gra Hill Aducation (Asia). 